\title{
The exquisite corpse for the advance of science
}

\section{Un cadavre exquis pour le progrès scientifique}

José de la Fuente ${ }^{1,2}$

${ }^{1}$ SaBio. Instituto de Investigación en Recursos Cinegéticos IREC-CSIC-UCLM, Ciudad Real, Spain. jose_delafuente@yahoo.com

${ }^{2}$ Department of Veterinary Pathobiology, Center for Veterinary Health Sciences, Oklahoma State University, Stillwater, OK 74078, USA.

Participants in the exquisite corpse:

- Sara Artigas-Jerónimo. PhD. student. SaBio, IREC-CSIC-UCLM, Spain. https://www.irec.es/en/personal/detalle/artigas-jeronimo-sara/

- Ricardo Brey. Visual artist. www.ricardobrey.com

- Elio Rodríguez. Visual artist. www.machoenterprise.com

- Armando Mariño. Visual artist. http://armandomarino.com

- Rafael López Ramos. Visual artist. http://www.lopezramos.info

- Alejandro Cabezas-Cruz. Researcher. UMR BIPAR, INRAE, ANSES, Ecole Nationale Vétérinaire d'Alfort, Université Paris-Est, France. www.neuropatick.com

- Christian Gortázar. Professor. SaBio, IREC-CSIC-UCLM, Spain. https://www.irec.es/en/personal/detalle/gortazar-schmidt-christian/

- Angel Delgado. Visual artist. www.angel-delgado.net

- Juan J. Pastor Comín. Professor. CIDoM-UCLM-CSIC, Facultad de Educación de Ciudad Real, Spain. http://juanjosepastor8.wix.com/home

ABSTRACT. The exquisite corpse or the exquisite cadaver (adapted from the French term "cadavre exquis") was invented by the Surrealists to reflect their delight in games, chance and the Freudian-based basis of the uncontrolled aspects of artistic production. It would be expected that the exquisite corpse creationist approach results in chaotic and meaningful pieces. However, these pieces with strange combinations could provide new views and interpretations of possible real situations. These features support that the exquisite corpse has not disappeared and can serve to inspire the creativity of scientists. The collaborations between science and art support and encourage the development of new methodological approaches to inspire scientists viewing previously unexplored properties when addressing scientific challenges. Herein, both scientists and artists participated when building the exquisite corpse. Then, the author put all pieces together randomly to build the exquisite corpse following a variant of the Surrealistic protocol and used the different exquisite corpse as an inspiration to ask questions that may advance research in the area of infectious diseases with emphasis on COVID-19.

KEYWORDS. Surrealism, infectious diseases, COVID-19, exquisite corpse, collaboration, art, science, immunology, alpha-Gal, music.

The exquisite corpse or the exquisite cadaver (adapted from the French term "cadavre exquis") was invented by the Surrealists to reflect their delight in games, chance and the Freudian-based basis of the uncontrolled aspects of artistic production. ${ }^{1,2}$ The exquisite corpse put into practice the theories of automatism through reducing the intervention of the author's conscious act to a minimum. To produce the exquisite corpse, a sheet of paper is first folded as many times as there are participants. Then, each participant takes a side of the folded paper and draws from top-to-down the different parts of the piece. None of the participants see other's contributions. Once the piece is complete, the last participant unfolds the sheet to reveal a composite piece made of previously unrelated forms that are now part of the same Surrealistic creation (Figure 1). A similar concept was used for individual Surrealists in some of their pieces (Figures 2 and 3). 


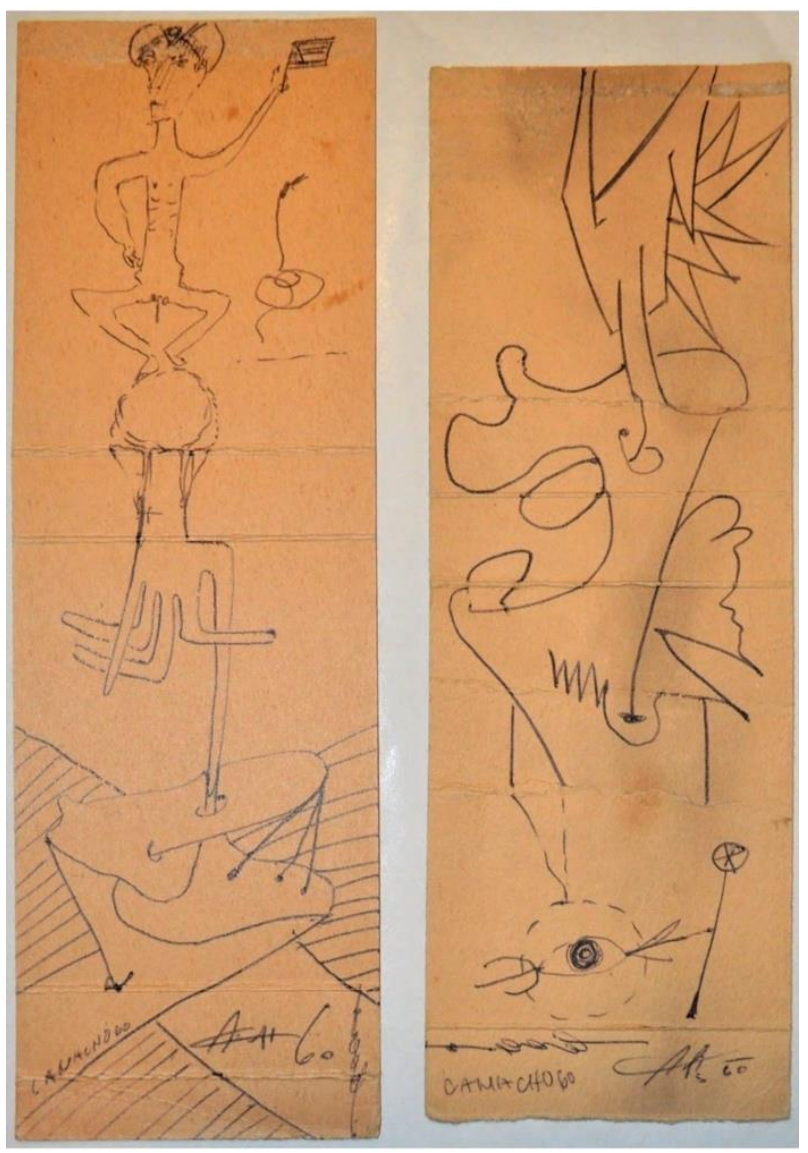

Figure 1. Jorge Camacho and Agustín Cárdenas. Exquisite corpse. Ink drawings on French cigarette packs Gitanes, 1960. 22.5 x 7.5 and $21 \times 7.5 \mathrm{~cm}$. Courtesy KGJ Collection, Spain.

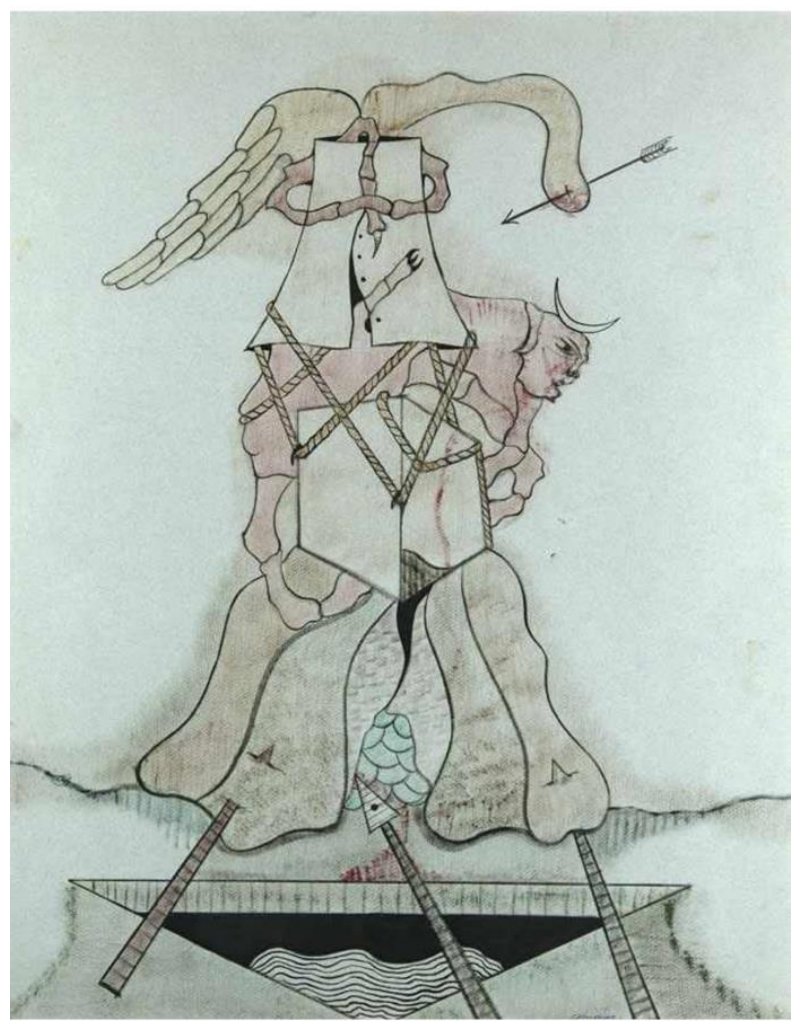

Figure 2. Jorge Camacho. Surrealistic composition. Pastel and ink on blue paper, ca. $1970.65 \times 50 \mathrm{~cm}$. Courtesy KGJ Collection, Spain. 


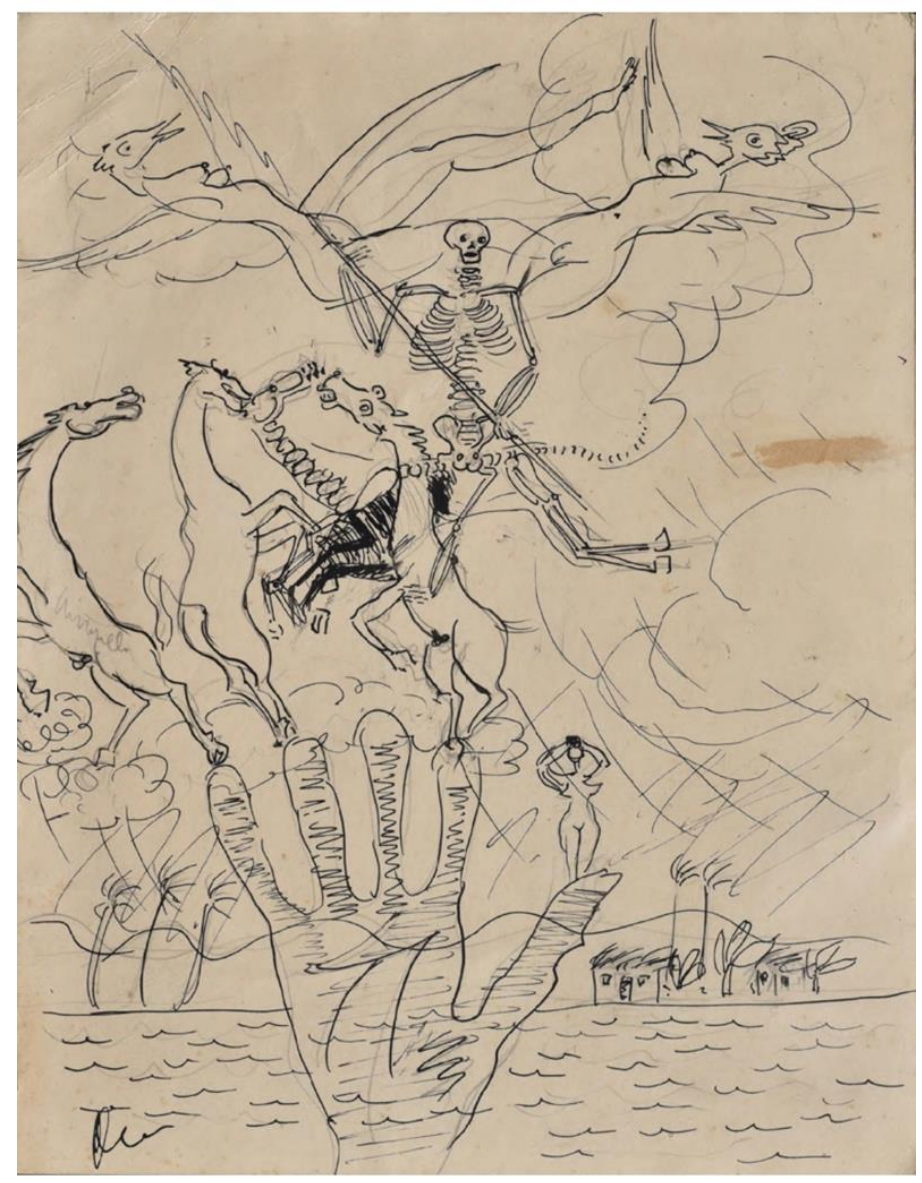

Figure 3. Carlos Enríquez. Surrealistic composition. Ink on paper, without date. 37 x $28 \mathrm{~cm}$. Courtesy KGJ Collection, Spain.

It would be expected that the exquisite corpse creationist approach results in chaotic and meaningful pieces. However, these pieces with strange combinations could provide new views and interpretations of possible real situations. These features support that the exquisite corpse has not disappeared and can serve to inspire the creativity of scientists. ${ }^{2}$

The collaboration between scientists and artists have resulted in innovative approaches to address scientific challenges in the areas of molecular biology and the control of emerging and reemerging infectious disesaes. ${ }^{3-6}$ The results derived from these collaborations between science and art support and encourage the development of new methodological approaches to inspire scientists viewing previously unexplored properties when addressing scientific challenges.

The exquisite corpse may be one of the new approaches to advance scientific research. Herein, both scientists and artists participated when building the exquisite corpse. In this case, scientists and artists submitted their pieces without seeing other's contributions. Finally, the author put all pieces together randomly to build the exquisite corpse following a variant of the Surrealistic protocol adapted to the current situation of confinement due to the COVID-19. Then, the author used the different exquisite corpse (Figures 4-8) as an inspiration to ask questions that may advance research in the area of infectious diseases. Due to the COVID-19 pandemic that has expanded rapidly worldwide and is causing millions of infected individuals and hundreds of thousands dead patients, questions inspired by constructed exquisite corpse were first focused on COVID-19 from the scientific perspective.

The scientific questions were focused on the possibility of boosting the immune response to Gala1-3Galß1-(3)4GlcNAc-R (alpha-Gal) for the control of infectious diseases affecting human 
health worldwide, including the COVID-19 pandemic. Despite the advances and potential impact that vaccines focused on the coronavirus represent for the prevention and control of COVID-19, interventions boosting the immune response with a broader and not pathogen-specific immunity may contribute not only to the control of COVID-19 but also to other pathogens that negatively affect the individual response to SARS-CoV-2. The immunization with alpha-Gal could be done through the oral/mucosal route by the use of probiotics based on microbiota bacteria with high alpha-Gal content. ${ }^{7-11}$ In addition to the protective immune response elicited by alpha-Gal immunization, the probiotics may also improve oral and lung microbiotas and exert bacterial interference against pathogens. Additionally, probiotic-based formulations have a low production cost and are easy to administer in regions with limited access to health services could have a major impact on the prevention and control of COVID-19 and other major infectious diseases worldwide.

In this way, the obtained exquisite corpse served for the inspiration of the following scientific questions:

The first exquisite corpse (Figure 4) suggested a scientist with the challenge to address a question relevant for global health. This question translated into is it possible to boost the immune response to alpha-Gal for the control of major infectious diseases? Preliminary evidences have shown the protective capacity of anti-alpha-Gal $\mathrm{IgM} / \mathrm{IgG}$ antibodies against pathogens with this modification on their surface, and support addressing this question to advance in the control of infectious diseases with a major impact on human health worldwide..$^{7-11}$

The second, third and fourth exquisite corpse (Figures 5-7) highlighted the mortality associated with the COVID-19 and the need to develop interventions for its control. To address this challenge, several questions were inspired by these pieces, (a) do SARS-CoV-2, the causative agent of COVID-19 and other coronaviruses contain alpha-Gal on their surface? (Figure 5), (b) are antialpha-Gal antibody levels affected by COVID-19? (Figure 6), and (c) is it possible to use the immune response against alpha-Gal for the control of COVID-19? (Figure 7).

In support to these questions, it has been shown that some viruses contain alpha-Gal on their envelope, which probably drove the "catastrophic" evolution that resulted in humans losing the capacity to synthesize this molecule and those developing an antibody response against it. ${ }^{9}$ Since SARS-CoV-2 and other coronaviruses come from wild animal hosts that do synthesize alpha-Gal, it is a possibility to explore and consider antibody-mediated opsonization for the prevention of virus zoonotic transmission. ${ }^{12}$ Previous results have shown differences in the anti-alpha-Gal antibody response in individuals infected with pathogens causing tuberculosis and malaria and in relation to other factors such as the ABO blood group. ${ }^{10}$ The answer to this question may be relevant to better understand the immune response mechanisms in COVID-19. Alpha-Gal elicits an immune response with a broader and non-pathogen-specific immunity ${ }^{13}$, which may contribute not only to the control of COVID-19 but also to potential reinfections by SARS-CoV-2-related genetic variants or other pathogens that negatively affect the individual response to SARS-CoV-2.

The last exquisite corpse (Figure 8) inspired a methodological question, is it possible to apply musical algorithms for a better understanding of protein evolution, structure, cell interactomics and quantum vaccinomics? Since the first algorithm was developed for the study of the sound of the DNA language ${ }^{14}$, recent developments encourage the application of musical algorithms in molecular biology and biomedicine. ${ }^{3,15}$ In this direction, an artificial intelligence (AI) algorithm was recently used by MIT researchers to translate the coronavirus protein structure into musing to advance the structural characterization of the virus. ${ }^{16}$

The approach using the collaboration between scientists and artists to construct the exquisite corpse resulted in new scientific questions. These questions cover some previously proposed but unexplored or not fully explored areas that could be addressed in future experiments to advance 
research in the area of molecular biology and the control of infectious diseases. ${ }^{12,17}$ The research methodology used here could be applied to other areas of biomedical, physical, chemical and social sciences while contribute also to the communication and dissemination of scientific research. Creative expression of scientific questions through poetry and literature can also advance research while enriching science education. ${ }^{18}$ This is another example of how the collaboration between scientists and artists can be implemented in different ways to potentially advance science and its impact on the society. The new methodological approaches based on the collaboration between scientists and artists create expectancy in that these innovative and open ways will indeed lead to successful and concrete scientific results in the future.
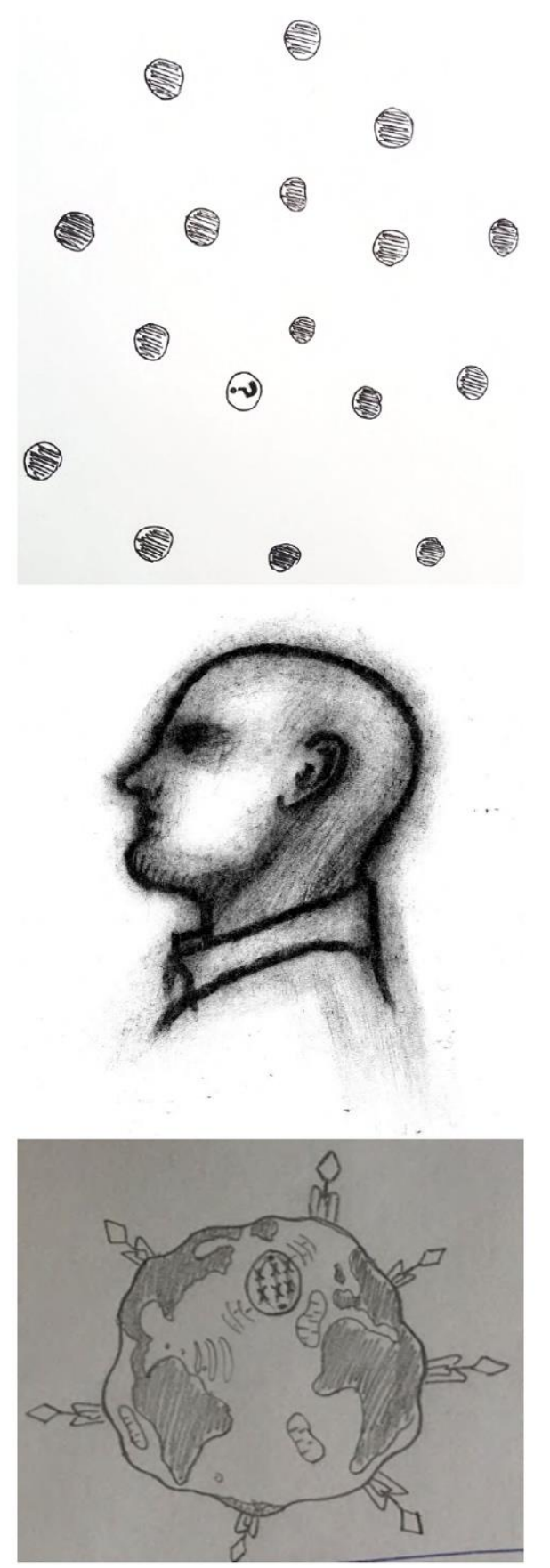

Figure 4. Is it possible to boost the immune response to Gala1-3Galß1-(3)4GIcNAc-R (alpha-Gal) for the control of major infectious diseases? Christian Gortázar (upper panel; pen on paper, courtesy of the scientist), Angel Delgado (central panel; crayon on paper, courtesy of the artist), Sara Artigas-Jerónimo (lower panel; pencil on paper, courtesy of the scientist). 


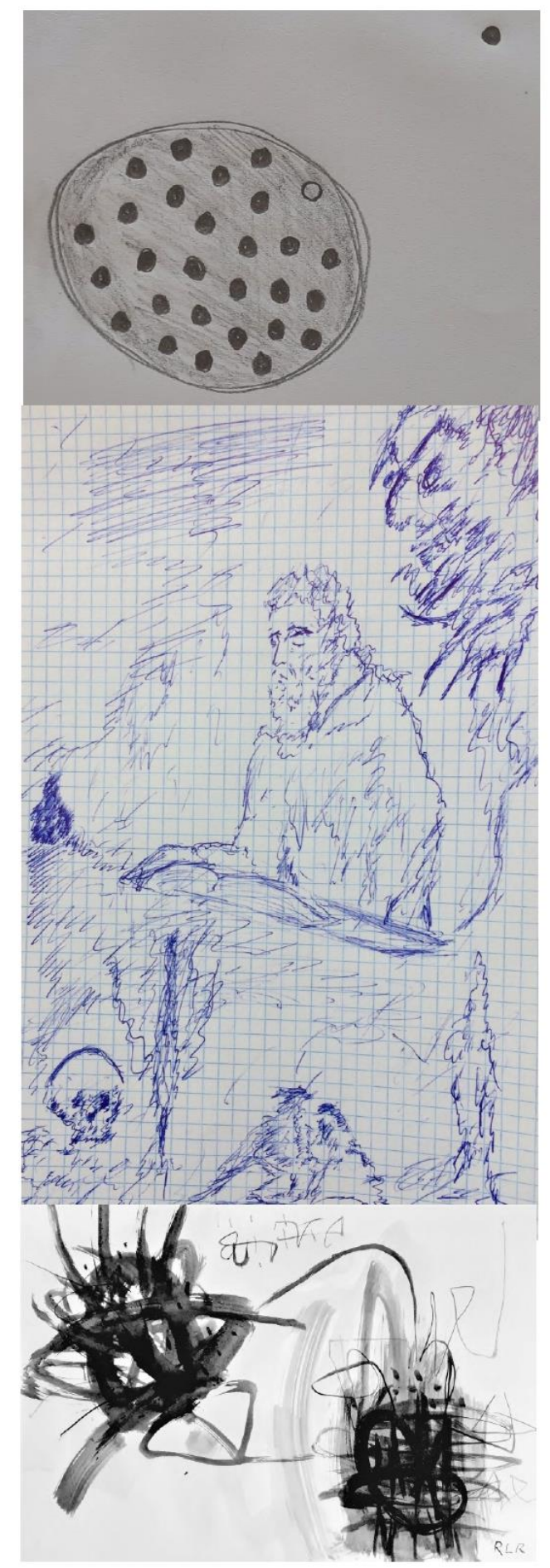

Figure 5. Do SARS-CoV-2, the causative agent of COVID-19 and other coronaviruses contain alpha-Gal on their surface? Alejandro Cabezas-Cruz (upper panel; pencil on paper, courtesy of the scientist), Juan J. Pastor Comín (central panel; pen on paper, courtesy of the scientist), Rafael López Ramos (lower panel; Indian ink on paper, courtesy of the artist). 


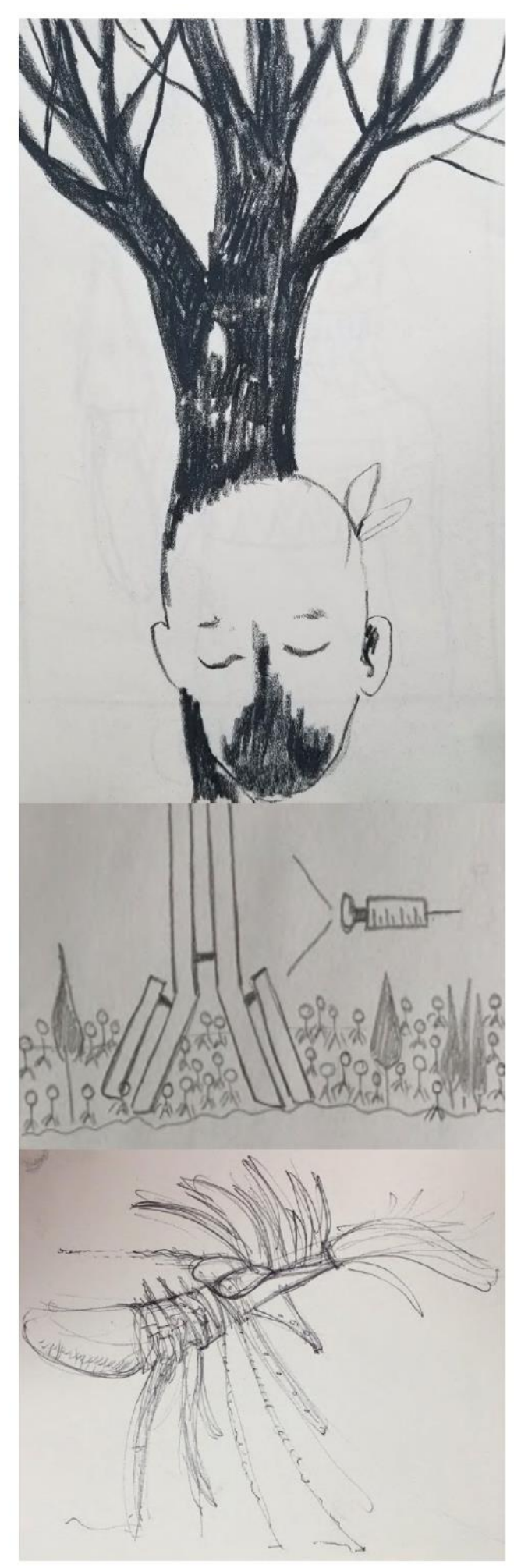

Figure 6. Are anti-alpha-Gal antibody levels affected by COVID-19? Armando Mariño (upper panel; charcoal on paper, courtesy of the artist), Sara Artigas-Jerónimo (central panel; pencil on paper, courtesy of the scientist), Elio Rodríguez (lower panel; pencil on paper, courtesy of the artist). 


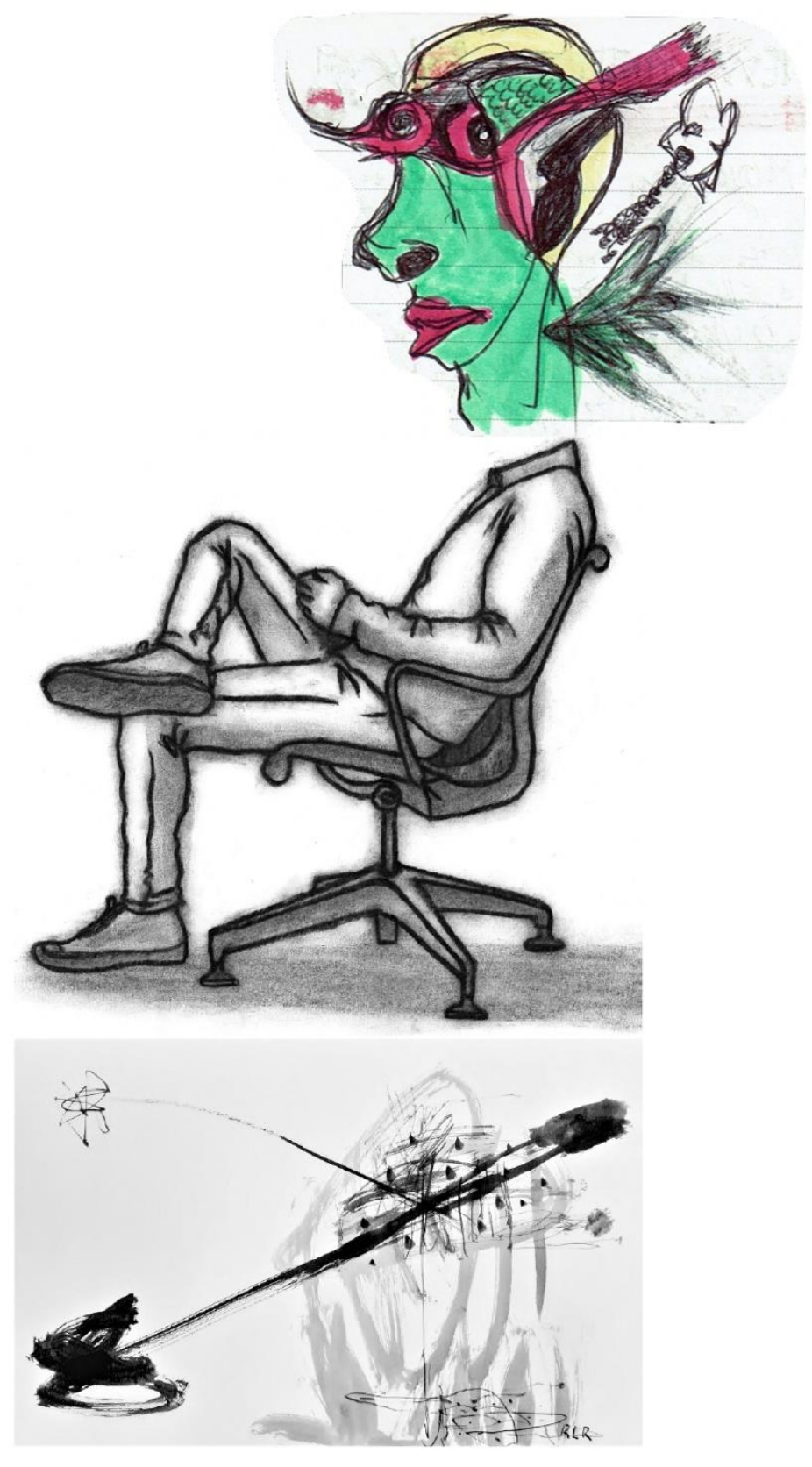

Figure 7. Is it possible to use the immune response against alpha-Gal for the control of COVID-19? José de la Fuente (upper panel; ink on paper, courtesy of the scientist), Angel Delgado (central panel; crayon on paper, courtesy of the artist), Rafael López Ramos (lower panel; Indian ink on paper, courtesy of the artist). 


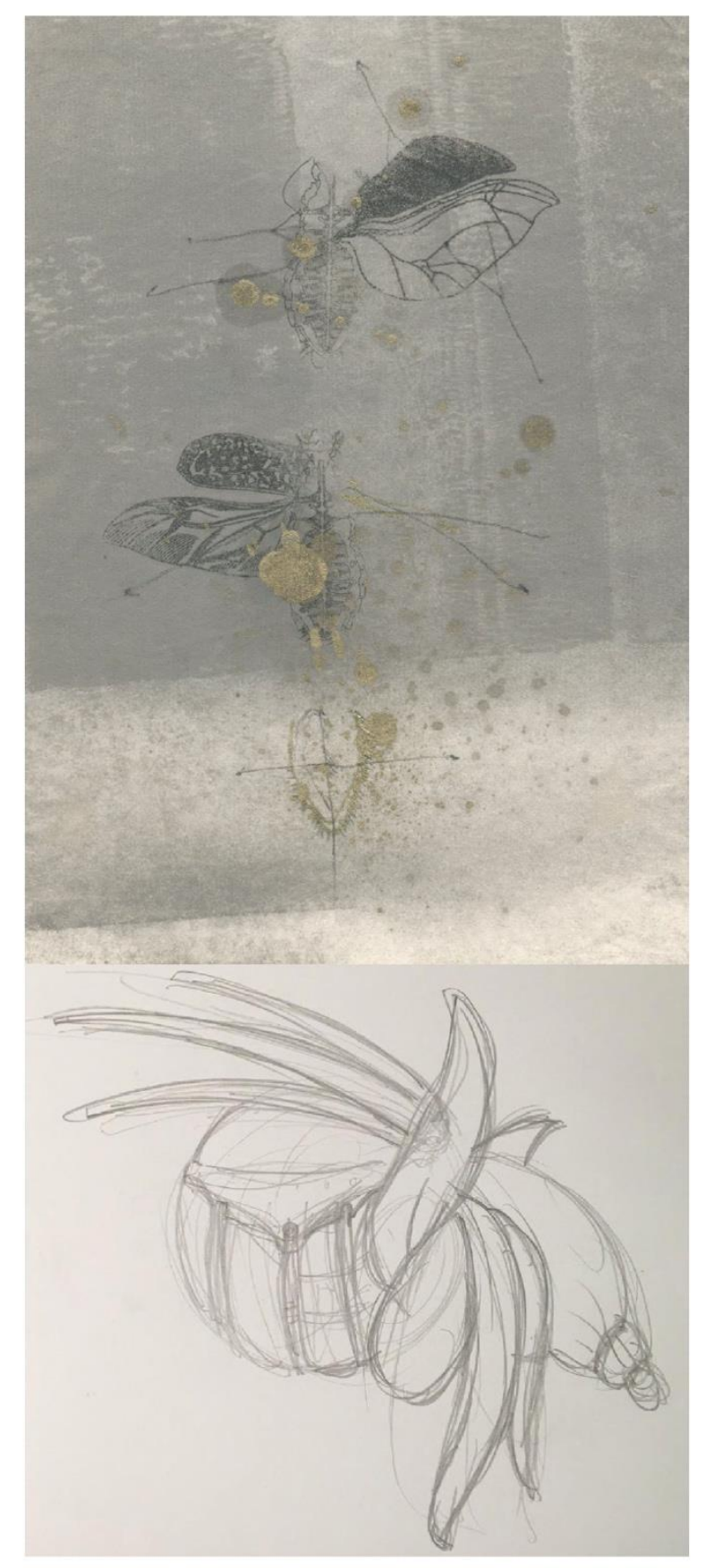

Figure 8. Is it possible to apply musical algorithms for a better understanding of protein evolution, structure and cell interactomics? Ricardo Brey (upper panel; ink, pencil and metallic paint on handmade paper, courtesy Alexander Gray Associates, Artists Rights Society ARS, NY, USA), Elio Rodríguez (lower panel; pencil on paper, courtesy of the artist). 


\section{References}

1. Gallego Fernández, R. Cadavre exquis (Exquisite cadaver). Museo Nacional Centro de Arte Reina Sofía, Madrid, Spain. https://www.museoreinasofia.es/en/collection/artwork/cadavre-exquis-exquisite-cadaver

2. Gotthardt, A. 2018. Explaining Exquisite Corpse, the Surrealist Drawing Game That Just Won't Die. https://www.artsy.net/article/artsy-editorial-explaining-exquisite-corpse-surrealist-drawing-game-die

3. Artigas-Jerónimo, S., Pastor Comín, J.J., Villar, M., Contreras, M., Alberdi, P., León Viera, I., Soto, L., Cordero, R., Valdés, J.J., Cabezas-Cruz, A., Estrada-Peña, A., de la Fuente, J. 2020. A novel combined scientific and artistic approach for advanced characterization of interactomes: the Akiri/Subolesin model. Vaccines 8: 77. https://doi.org/10.3390/vaccines8010077

4. de la Fuente, J. 2018. Anaplasmosis: What we can learn from Lam's surrealistic animalarium. Hektoen International, Hektorama-Infectious Diseases-Summer 2018. http://hekint.org/2018/08/23/anasplasmosiswhat-we-can-learn-from-lams-surrealistic-animalarium/

5. de la Fuente, J., Estrada-Peña, A., Cabezas-Cruz, A., Brey, R. 2015. Flying ticks: anciently evolved associations that constitute a risk of infectious disease spread. Parasit. Vectors 8: 538. https://doi.org/10.1186/s13071-015-1154-1

6. Eldred, S.M. 2016. Art-science collaborations: Change of perspective. Nature 537: 125-126. https://doi.org/10.1038/nj7618-125a

7. Cabezas-Cruz, A., Hodžić, A., Román-Carrasco, P., Mateos-Hernández, L., Duscher, G.G., Sinha, D.K., Hemmer, W., Swoboda, I., Estrada-Peña, A., de la Fuente, J. 2019. Environmental and molecular drivers of the $\alpha$-Gal syndrome. Front. Immunol. 10: 1210. https://doi.org/10.3389/fimmu.2019.01210

8. de la Fuente, J., Pacheco, I., Villar, M., Cabezas-Cruz, A. 2019. The alpha-Gal syndrome: new insights into the tick-host conflict and cooperation. Parasit. Vectors 12: 154. https://doi.org/10.1186/s13071-019-3413-Z

9. Galili, U. 2019. Evolution in primates by "Catastrophic-selection" interplay between enveloped virus epidemics, mutated genes of enzymes synthesizing carbohydrate antigens, and natural anticarbohydrate antibodies. Am. J. Phys. Anthropol. 168: 352-363. https://doi.org/10.1002/ajpa.23745

10. Cabezas-Cruz, A., Mateos-Hernández, L., Alberdi, P., Villar, M., Riveau, G., Hermann, E., Schacht, A., Khalife, J., Correia-Neves, M., Gortazar, C., de la Fuente, J. 2017. Effect of blood type on anti- $\alpha-G a l$ immunity and the incidence of infectious diseases. Exp. Mol. Med. 49: e301. https://doi.org/10.1038/emm.2016.164

11. Cabezas-Cruz, A., de la Fuente, J. 2017. Immunity to $\alpha$-Gal: towards a single-antigen pan-vaccine to control major infectious diseases. ACS Cent. Sci. 3: 1140-1142. https://doi.org/10.1021/acscentsci.7b00517

12. de la Fuente, J., Gortázar, C., Cabezas-Cruz, A., Contreras, M., Villar, M., Pacheco, I., Arias, A., Mas, A. 2020. Boosting anti-alpha-Gal immune response to control COVID-19. Royal Society Open Science Stage1 Registered Report, date of in-principle acceptance: 15/4/2020. https://doi.org/10.17605/OSF.IO/XHDPU

13. Contreras, M., Pacheco, I., Alberdi, P., Díaz-Sánchez, S., Artigas-Jerónimo, S., Mateos-Hernández, L., Villar, M., Cabezas-Cruz, A., de la Fuente, J. 2020. Allergic reactions and immunity in response to tick salivary biogenic substances and red meat consumption in the zebrafish model. Front. Cell. Infect. Microbiol. 10: 78. https://doi.org/10.3389/fcimb.2020.00078

14. Riego, E., Silva, A., de la Fuente, J. 1995. The sound of the DNA language. Biol. Res. 28: 197-204.

15. Qin, Z., Buehler, M.J. 2019. Analysis of the vibrational and sound spectrum of over 100,000 protein structures and application in sonification. Extreme Mech. Lett. 29: 100460. https://doi.org/10.1016/j.eml.2019.100460

16. Macaulay, T. 2020. MIT researchers use AI to turn the coronavirus into a haunting melody. TNW. https://thenextweb.com/neural/2020/04/06/mit-researchers-use-ai-to-turn-the-coronavirus-into-a-haunting-melody/

17. Pacheco, I., Contreras, M., Villar, M., Risalde, M.A., Alberdi, P., Cabezas-Cruz, A., Gortazar, C., de la Fuente, J. 2020. Vaccination with alpha-Gal protects against mycobacterial infection in the zebrafish model of tuberculosis. Vaccines 8: 195. https://doi.org/10.3390/vaccines8020195

18. Brown SA. Creative expression of science through poetry and other media can enrich medical and science education. Front Neurol. 2015 Jan 22;6:3. https://doi.org/10.3389/fneur.2015.00003 